\title{
Eliciting Collaboration From "Risky" States: The Limits of Conventional Multilateralism in Security Affairs
}

\author{
GERALD SCHNEIDER AND PATRICIA A. WEITSMAN
}

The emergence of an increasing number of states with a high conflict propensity constitutes a major challenge to international relations theory. While realist approaches dismiss the capacity of international governmental organisations to deal with "risky" states, liberal approaches largely focus on the successful multilateral management of peace. In this article, we examine how international institutions can counter the threats posed by "risky" states. Our analysis shows that current scholarship on multilateralism does not pay sufficient attention to the wider strategic context of international co-operation in security affairs. In particular, we argue that liberal approaches underestimate the ability of actors external to an institution to disrupt the collective attempts to elicit co-operation from "risky" states. The article offers a model-based typology of multilateral mechanisms and discusses the limits of current strategies from the viewpoint of non-co-operative game theory.

\section{International Governance in the Presence of "Risky States"}

"The United Nations should come in and take over Liberia, not temporarily, but for life", said George M. Weah, a Liberian soccer player in an interview with the New York Times, "to make Liberians believe in democracy, to make us believe in human rights, they need to go in and just seize control of the country". ${ }^{2}$ While this level of faith in the capacity of multilateral institutions to resolve effectively devastating conflicts is perhaps greater than most, it does reflect an increased tendency to call upon the UN and other international organisations to intervene in the trouble spots of the 1990s. The proliferation of institutional activity implies the need for systematic investigation into the effectiveness of collective mecha-

1. Previous versions of this article have been presented at a workshop on multilateralism in security affairs, Ohio University, Athens, Ohio, 15-17 June 1995, the second Pan-European Conference in International Relations, Fondation Nationale des Sciences Politiques, Paris, 13-16 September 1995 and the Annual Convention of the International Studies Association, San Diego, CA, 16-20 April 1996. We would like to thank John A.C. Conybeare, James D. Morrow, Arild Underdal and the participants for helpful comments. Some elements of this article will appear in the introduction and the conclusion to Gerald Schneider and Patricia A. Weitsman (eds.), Enforcing Cooperation: "Risky" States and the Intergovernmental Management of Conflict (London: MacMillan, 1996).

2. Howard W. French, "Soccer Hero voices Liberia's Anguish", NYT, 5/20/96, A4. 3. 
nisms for eliciting cooperation from target states. As multilateral interventions for dispute resolution increasingly supersede unilateral interventions in number and resource allocation, the unique problems associated with institutional activity need to be identified. ${ }^{3}$ The challenges presented to the international community in seeking to facilitate cooperation from what we call "risky states" have not yet been systematically identified and explored, nor have the possible strategies available to institutions.

In this article, we develop a strategic approach that helps us to understand the limitations of the extant scholarship on multilateralism in security affairs. In our view, the weaknesses of existing institutional strategies-which involve a mixture of rewards, promises, reconciliation, threats, and punishments-go beyond the difficulties associated with collective action. ${ }^{4}$ Current multilateral practices are predicated on static concepts which ignore the capacity of risky states to exploit international institutions. In other words, the strategic aspects of relations between institutions and risky states have to date been neglected. While most studies focus on the international decision making of international organisations, the approach presented in this paper can help us understand, for example, the increasing frequency of overt challenges to multilateral troops put in place to mitigate lingering conflicts and to prevent human rights abuses.

Instead of viewing the collective action problem as one which is exclusively internal to an institution, and thereby implying that if consensus were attained action would be effective, it is possible to see that difficulties in attaining consensus may affect the interaction between the institution and target state. Internal difficulties in deciding on a course of action may signal insufficient resolve to the risky state; the credibility of an institutional threat will be weakened, and deterrence may fail. In other words, what becomes critical in the context of threats and promises is the signalling game between the institution and the target actor. In the case of rewards and punishments the problem is one of adverse selection: the international community may inadequately respond to states with high conflict propensity because it fails to recognise the dangers. Similarly, the international community might overreact by judging the target state to be riskier than it actually is. Asymmetric information and uncertainty about the permanence of compliance with the demands by the international community may distort the outcomes as well: multilateral actors might reward risky states which do not alter their behaviour over the long run, or punishments might be inflicted despite the risky state's intent to comply with the institution's demand.

Although international institutions have been partially successful in generating co-operative behaviour under certain conditions, political elites still have significant incentives to employ force to resolve questions of national identity and independence. In this article, we analyse systematically the most important multilateral strategies in security affairs.

3. For a data analysis of this trend, see Lionel Marquis and Gerald Schneider, "Vermittlungsaktionen in militärischen Konflikten der Nachkriegszeit im Zeitraum 1945-1994", Swiss Political Science Review (forthcoming).

4. Mancur Olson, The Logic of Collective Action (Cambridge, MA: Harvard University Press, 1965). See also Todd Sandler, Collective Action (Ann Arbor, MI: University of Michigan Press, 1992). 
In the following section, we define the notion of risky states and discuss the importance of international governance. We summarise the relevant theoretical work in this area, and then address the background conditions of the emergence of risky states. The third section offers an ideal type analysis of multilateral mechanisms and some empirical illustrations. In the fourth section, we point out some of the problems these institutions face and discuss the theoretical implications of our work. A conclusion summarises and points out future avenues of research.

\section{Theoretical Context and Basic Definitions}

The global community has witnessed that some states can suddenly overstep the courant normal, thereby precipitating a major security crisis. For example, the "brinkmanship" strategy used by some nuclear have-nots which threaten to develop an atomic potential in order to attain their goals is becoming increasingly commonplace. It is also becoming more customary that states threaten to persecute minorities or obstruct multilateral peacekeeping efforts.

It would certainly appear that the number of risky states has grown dramatically throughout the past decade. According to one account, the year 1994 witnessed 37 wars, almost $20 \%$ of the 186 wars initiated since the end of World War II. ${ }^{5}$ Another source speaks of a relative decline in this year, but points out the importance of low-level disputes. ${ }^{6}$ Much of the militarised conflict involving risky states has been ethnopolitical. Gurr reports an increase in the numbers of ethnopolitically motivated conflict involvements from 62 in the years 1980-1989 to 70 in 1993 and 1994 alone. ${ }^{7}$ However, not all of the risks are rooted in ethnic nationalism. Fearon convincingly argues that ethnic attachments are products of social and political structures; that is, politicians might manipulate issues to such an extent that the "ethnification" of politics becomes a viable option. ${ }^{8}$

Accordingly, we conceptualise risky states as those which are governed by leaders with a tendency to solve problems through military means. This might involve a general preference for the violent response to a political problem, but also includes the acceptance of the gamble between military escalation and negotiations more often than other states do. In terms of utility theory, such an actor has a risk-prone tendency.

Brqadly conceived, risky states pose major security problems to the international community in one or more of the following ways: (a) these states or actors do not abide by the conventional and core norms of international

5. Klaus Jurgen Gantzel, "Die Kriegsherde der Welt", Der Burger im Staat, Vol. 45, No. 1.

6. Peter Wallensteen and Margareta Sollenberg, "After the Cold War: Emerging Patterns of Armed Conflict", Journal of Peace Research, Vol. 32, No. 3. See also Peter Wallensteen, Peter and Karin Axell,

"Armed Conflict at the End of the Cold War", Journal of Peace Research, Vol. 30, No. 3.

7. Ted Robert Gurr, "Peoples Against States: Ethnopolitical Conflict and the Changing World System", International Studies Quarterly Vol. 38, No. 3 (1994). See also Ted Robert Gurr, Minorities at Risk (Washington DC: USIP Press, 1993) and Ted Gurr and Barbara Harff, Ethnic Conflict in World Politics

(Boulder: Westview, 1994).

8. James D. Fearon, "Ethnic Conflict as a Commitment Problem", Unpublished Manuscript, University of Chicago (1994), p. 5. For a similar analysis, see Robert H. Bates and Barry R. Weingast, "A New Comparative Politics: Integrating Rational Choice and Interpretivist Perspectives", Typescript, Harvard University/Stanford University (1994). 
community in more than an isolated incident; (b) they are perceived to conduct policies which are volatile or uncertain; (c) they are situated in a dangerous strategic context such as a rivalry or conflict-prone region; and (d) have a propensity to employ force domestically or internationally.

These indicators of risky states have three facets. First, these political entities may have a propensity to pursue goals which most other states morally condemn. In other words, there is far-reaching consensus in the global community that action must be taken to deal with the security problem posed by the state. However, a risky state can be both at risk and pose a risk. It is open to normative judgment whether a risky state is an aggressor in an armed conflict or not. In this article, we use the concept in a purely descriptive sense, recognising that both the environment and the inclination contribute to risky behaviour.

The second facet of riskiness has to do with rationality. In our view, risky states are generally rational in the sense that they react to incentive structures. This means that most leaders of such groups are not "crazy" or even completely "irrational". 9 However, some risky states might try to behave "irrationally" to reach their goals and seek to create uncertainty about the sanity of their actions. ${ }^{10}$ We also acknowledge the possibility of "bounded rationality"11 or even "irrationality". In the former case, the reliance on specific learning mechanisms leads states to select strategies that do not seem optimal from the perspective of a Bayesian agent. In the latter case, agents cannot even detect the optimal course of action, and they systematically make mistakes in their choices. Although evolutionary game theory suggests that bounded rationality does not necessarily pose a problem in the long run, it might be crucial in the short run; there might not be sufficient time to learn. Even if institutional actors fully intend to implement the threats they make, and should thus be deemed credible, deterrence might fail. An additional problem in this context is how states enforcing cooperation should deal with actors that do not respond appropriately or rationally to the incentives offered by the international community.

The third element of our definition of risky states is that it incorporates state-level explanations. Instead of speculating about the motives behind foreign policy choices, we argue that different nation state attributes might contribute to an increased risk propensity. ${ }^{13}$ Military preparedness might be one aspect of the riskiness of a state in general; the correlation of arms expenditures of one state with another state might be an indicator of how risky a state or a dyad is. ${ }^{14}$

9. This point has already been made by Dror who attacked Western deterrence theorists for their alleged failure in the correct handling of what he calls "crazy" states. See Yehezkel Dror, Crazy States: A Counterconventional Strategic Problem (Millwood, NY: Kraus Reprint, 1980) (1st edn, 1971).

10. Thomas Schelling, Arms and Influence (New Haven: Yale University Press, 1966).

11. Thomas J. Sargent, Bounded Rationality in Macroeconomics (Oxford: Oxford University Press, 1993).

12. For introductions to these recent results, see for instance Eric Van Damme "Evolutionary Game Theory", European Economic Review, Vol. 38 (1994); and Jurgen W. Weibull, "The 'As If' Approach to Game Theory: Three Positive Results and Four Obstacles", European Economic Review, Vol. 38 (1994).

13. For an insightful critique of these approaches, see Jack S. Levy, "The Diversionary Theory of War: A Critique", in M.I. Midlarsky (ed.), Handbook of War Studies (Ann Arbor: University of Michigan Press, 1989).

14. John A.C. Conybeare, "A Portfolio Diversification Model of Alliances", Journal of Conflict Resolution, Vol. 36, No. 1 (1992). 
Table 1. Potential security issues and impediments to effective multilateral action according to the level of analysis

\begin{tabular}{llllll}
\hline Unit of analysis & Individual & State & Dyad & Region & System \\
\hline $\begin{array}{l}\text { Main security } \\
\text { problem }\end{array}$ & "Irrationality" & Risky State & Rivalry & $\begin{array}{c}\text { Multilateral } \\
\text { conflict }\end{array}$ & Polarity \\
$\begin{array}{l}\text { Problem for } \\
\text { multilateralism }\end{array}$ & $\begin{array}{c}\text { Manipulation of } \\
\text { uncertainty }\end{array}$ & $\begin{array}{c}\text { Strategic } \\
\text { exploitation }\end{array}$ & $\begin{array}{c}\text { Neutrality of } \\
\text { multilateral agent }\end{array}$ & $\begin{array}{c}\text { Diffusion of } \\
\text { conflict }\end{array}$ & $\begin{array}{c}\text { Balance of } \\
\text { power }\end{array}$ \\
\hline
\end{tabular}

Table 1 summarises the concept of risky actors within the wider theoretical context about the appropriate level of analysis, and the potential problem posed to a multilateral institution.

At the individual level of analysis, ${ }^{15}$ government leaders might deliberately create uncertainty about their preferences or about their future courses of action. Further, at the individual level, perceptions become important. State leaders may interpret the intentions and potential actions of an institution as benign or impotent, opening up avenues of action that they believe will go unchallenged. As Jervis notes, "it is often impossible to explain crucial decisions and policies without reference to the decision-maker's beliefs about the world and their images of others". ${ }^{16}$ This would be especially true in looking for differences among individuals' risk preferences and deviations from stringent forms of rationality. As outlined above, individuals who appear to be "irrational", whether they are conscious of promoting this image or not, will seem undeterrable to the international community. This will make the multilateral agent's decision about how to deal with that actor difficult.

At the state level of analysis, the notion of the risky state emerges. A central problem faced by the international community will be the effectiveness of collective action, and the potential for risky states to exploit the multilateral institution. Again, as at the individual level of analysis, the state will have opportunities to divide an international coalition, and drive a wedge between member states of an institution. This may disrupt effective action on the part of an organisation.

One state alone, however, does not necessarily create a risk. The literature on the "democratic peace" has shown that certain behaviour may not be detected unless examined in the strategic context of two or more states. ${ }^{17}$ For our purposes, this suggests that a state may not appear to be risky in and of itself, but may be when viewed in conjunction with another state. Riskiness in dyads may manifest itself in "rivalries"; that is, pairs of states which experience recurrent conflict. A central difficulty risky rivalries pose to multilateral institutions is that, for the most part, it is impossible to intervene in the dispute and

15. In many ways, when analysing risky states, the individual and state level of analysis may be used interchangeably. This depends on the state type, and the extent to which the head of state has absolute power over policy decisions.

16. Robert Jervis, Perception and Misperception in International Politics (Princeton, NJ: Princeton University Press, 1976), p. 28.

17. A summarising statement is Bruce Russett, Grasping the Democratic Peace (Princeton, NJ: Princeton University Press, 1993). 
simultaneously maintain neutrality. At the regional level, riskiness (in contrast to "security communities" or "zones of peace") is manifest in the potential for a bilateral conflict to become linked to other disputes and spread; i.e., that there is diffusion. ${ }^{18}$ The central task of a multilateral agency would be to contain the area of conflict. At the systems level of analysis, the most salient security issue to a multilateral agent will be imbalances of power, and uncertainty arising from the polarity of the system. The multilateral response to these problems is to form an alliance. The issue then becomes how one multilateral institution addresses security threats arising from another multilateral institution or alliance.

The extent to which multilateral institutions will be effective at the systemic level will vary with the power capabilities of the risky state, and the fluidity of the system. Attempts to pacify risky states during periods of systemic transformation are particularly problematic since the norms of behaviour are often in flux. During these periods, there will be greater opportunities for risky states. By the same token, however, great powers may have more at stake, and more incentives to meet the challenges posed by risky states in order to maintain the status quo. In an era of global change, long term mechanisms will be potentially more effective than during other periods because the risky state faces relatively broad opposition, and the carrots and sticks proffered to the risky state will be more substantial than during other periods. However, the global community will be impotent in countering strong states challenging the status quo and violating norms of international conduct, unless the behaviour is truly grievous.

\section{Risky States and Multilateral Institutions}

Multilateral institutions have become important in the management of conflicts involving risky states. However, organisations like the UN, the European Union, and the Organisation for Security and Cooperation in Europe have not lived up to the international community's high expectations in the post Cold War period. In fact, in the case of UN peacekeeping attempts in Bosnia, the forces have shown themselves to be both impotent and vulnerable. The ineffectiveness of some of these efforts raises the question of whether or not the design of the multilateral mechanisms is flawed. A systematic analysis of the functioning of the basic mechanisms might help to illuminate the root of some weaknesses in the current practice of international conflict management.

As a first step in the process of understanding why conflict management is difficult via institutions, it is possible to distinguish the dynamics internal to the institution, and those external to it which inhibit or facilitate institutional effectiveness. With respect to the former category, neoliberal institutionalists focus on the collective action problem. In their view, the public good nature of

18. The classic work on security communities is Karl W. Deutsch, Sidney A. Burrell, Robert A. Kann, Maurice Lee, Jr., Martin Lichterman, Raymond E. Lindgren, Francis L. Loewenheim and Richard W. Van Wagenen, Political Community and the North Atlantic Community (Princeton, NJ: Princeton University Press, 1957). For recent work on this issue see Emanuel Adler and Michael N. Barnett "Security Communities", Paper presented at the Annual Meeting of the American Political Science Association, New York, 1-4 September 1994. And Gerald Schneider, "Integration and Conflict: The Empirical Relevance of 'Security Communities'", Typescript, University of Bern (1995). 
"security" frustrates institutional action. As Mancur Olson writes in his classic treatise on collective action:

Any group or organization, large or small, works for some collective benefit that by its very nature will benefit all of the members of the group in question. Though all of the members of the group therefore have a common interest in obtaining this collective benefit, they have no common interest in paying the cost of providing that collective good. Each would prefer that the others pay the entire cost, and ordinarily would get any benefit provided whether he had borne part of the cost or not. ${ }^{19}$

What becomes important here, as well, is the number of states in the institution. The problem of "free riding" on other members' contributions to procure a collective good, as is security or stability of the international system, or to take action vis a vis a risky state, will be more difficult to resolve the greater the number of participating states. In Olson's view, "the larger the group, the less it will further its common interests". ${ }^{20}$

If institutions are to provide any deterrent value at all or signal resolve to a risky state contemplating action in violation of global norms, internal disputes over burdensharing and free riding will signal weak credibility. We will return to this point below.

Realists and neorealists also see the internal dynamics of institutions as governed by individual states' self interest. Participation in an international institution does nothing to mitigate the anarchical nature of international politics; states are interested in pursuing power at best, or at least survival. Cooperation within an institution will be inhibited by the multitude of national interests involved. This is the main reason why realists expect little external effects of multilateral organisations in security affairs. In their opinion, international institutions are little more than vehicles for powerful states to establish the rules and norms of action. In an important amendment to structural realism, Gowa posits that trade increases economic efficiency and enables states to employ resources for military purposes. Yet, the anarchy of the international system partly offsets this effect by rendering possible adversaries more powerful, limiting the scope of international collaboration to like-minded states. ${ }^{21}$

Neoliberals have a completely different view on the external effects of multilateral frameworks. While institutions and regimes may be more difficult to create and sustain within the security sphere than within the realm of international economics, ${ }^{22}$ once created, they may deepen over time and facilitate "collaboration, co-ordination, and involuntary defection problems" if the informational role of the institutions is substantial. ${ }^{23}$ As Smith writes, this may

19. M. Olson, The Logic of Collective Action, op. cit., p. 21.

20. Ibid., p. 36 .

21. Gowa, op. cit. For recent reviews of this literature, see David A. Lake, "Leadership, Hegemony, and the International Economy: Naked Emperor or Tattered Monarch with Potential?", International Studies Quarterly, Vol. 37, No. 4 (1993); and Jarrod Wiener, "'Hegemonic' Leadership: Naked Emperor or the Worship of False Gods?", European Journal of International Relations, Vol. 1, No. 2 (1995).

22. Robert Jervis argues that the heightened level of competitiveness and the magnitude of the consequences of obtaining a "sucker" pay-off are especially important in this respect. See his "Security Regimes", in Stephen D. Krasner (ed.), International Regimes (Ithaca: Cornell University Press, 1983).

23. Wallander and Keohane, op. cit., p. 18. 
enhance cooperation in the long term, because "institutionalisation is the process by which norms and rules acquire value and legitimacy, and as such may serve as a reliable indicator of the convergence of expectations". ${ }^{24}$ Once expectations are stabilised, cooperation may endure. Neoliberals argue that international institutions matter in influencing co-operative outcomes among states by resolving the co-ordination problems. Difficulties in eliciting co-operation arise not from true conflicts of interest, but rather, from co-ordination problems which plague the actors in the system. Institutions facilitate co-operation by reducing transaction and information costs, providing enhanced transparency, promoting issue-linkage, enlarging the shadow of the future, and reinforcing reciprocity. ${ }^{25}$ Further, institutions and regimes may work toward resolving dilemmas of common interests and dilemmas of common aversions. ${ }^{26}$

While these insights inform us on the general role institutions play in facilitating inter-state cooperation, current scholarship vastly underestimates the importance of the strategic relationship between the "sender" and the "target" of a multilateral policy. Although there are some unorthodox perspectives on sanctions, ${ }^{27}$ most research on security multilateralism focuses on the decision making dynamics internal to the institution in question. ${ }^{28}$ The collective action problem and the multitude of interests of the member states does frustrate action within an institution. This, however, is only a part of the problem. If achieving consensus within an institution is difficult, this will signal weak resolve to a risky state. Given that information about the decision making within international institutions like the $\mathrm{UN}$ is easily accessible, the risky state would have a clear idea as to whether action would be likely and could decide its move accordingly. Putting the interaction between the risky state and the international institution adds an interesting twist to the extant literature on multilateralism in security affairs.

This perspective is in sharp contrast to the prevailing scholarship. Although liberal approaches point out the importance of information inefficiencies and transaction costs, their focus is primarily internal, rather than seeing also the external interaction. They do not analyse how states outside of the collaborative web of international institutions might attempt to disrupt the multilateral framework prior to its decision to act. This is particularly important in security affairs where collective action cannot sensibly be understood without a focus on the hindrances in pursuing the goal of reducing a common threat. Dealing with the larger strategic interaction allows us to analyse the logic of the multilateral mechanisms that are used to deal with risky states. In other words, international governance may be possible, although it might be provided at a

24. Roger K. Smith, "Institutionalisation as a Measure of Regime Stability: Insights for International Regime Analysis from the Study of Domestic Politics", Millenium: Journal of International Studies, Vol. 18, No. 2 (1989), p. 229.

25. Axelrod and Keohane, op. cit.

26. Arthur A. Stein, Why Nations Cooperate (Ithaca: Cornell University Press, 1990), esp. Ch. 2.

27. See, e.g. William Kaempfer and Anton D. Lowenberg, "Analyzing Economic Sanctions: Toward a Public Choice Framework", in John S. Odell and Thomas D. Willett (eds.), International Trade Policies (Ann Arbor: University of Michigan Press, 1990) and Edward D. Mansfield, "International Institutions and Economic Sanctions", World Politics, Vol. 47, No. 4 (1995).

28. See for instance Steve Weber, "Shaping the Postwar Balance of Power: Multilateralism in Nato", International Organization, Vol. 46, No. 4 (1992). 
suboptimal level due to the presence of risky states and the internal free-riding problems.

This could lead to more informed analysis of the ability of the international community to develop and implement collective security institutions. Realists have been sceptical about the capacity of collective security mechanisms to operate appropriately. The central criticism focuses on the difficulties associated with collective action; states would fail to honour their commitment to counter aggression when it occurred. ${ }^{29}$ In the liberal view, conversely, collective security, as a pact among states to "join a coalition to confront any aggressor with opposing preponderant strength", ${ }^{30}$ provides an effective deterrent for at least some of the risky states that seek to challenge the status quo. Three variables influence the effectiveness of multilateral arrangements: the number of states that are vulnerable to collective sanctions; the existence of a consensus among the major states about what constitutes a violation of international order; and a shared sense among the major states that the welfare of the international community is essential. ${ }^{31}$

It becomes apparent in this context, however, that the grand design of security organisations may not always be the appropriate issue to examine. The interaction between a risky state and an institution may depend on certain contextdependent issues affecting the cost-benefit calculations of both actors, e.g. to what extent is the action a threat to a core value on the part of the international community, or a multilateral institution already in place? How powerful is the challenger? The lack of an effective collective security system does not in any way imply that collective action is not possible or likely; nor is the existence of a security institution an indication of the effectiveness of its mechanisms designed to elicit cooperation. The specific multilateral mechanisms themselves require close and systematic examination. After doing so, we might better be able to speak to the issue of which kind of institution can more successfully employ the most effective institutional mechanisms. Given that credibility is crucial, and given the fact that risky states may exploit and thus diminish the effectiveness of security measures even if collective action is taken, a micro-level approach to understanding multilateral effectiveness is necessary. This sort of analysis widens the scope of available means for the international community to elicit cooperation, and goes beyond the theoretical stalemate between liberalism and realism. We then are able to identify problems otherwise unnoticed; for example, one reason why multilateral action is difficult is the presence of risky states. Since such actors systematically undermine attempts to provide security, theories of multilateral action in security affairs have to make the strategic relationship between the sender of a collective policy and its target explicit.

29. Richard Betts, "Systems for Peace or Causes of War? Collective Security, Arms Control, and the New Europe", International Security, Vol. 17, No. 1, pp. 211-214.

30. Charles A. Kupchan and Clifford A. Kupchan, "Concerts, Collective Security and the Future of Europe", International Security, Vol. 16, No. 1 (1991), p. 118.

31. Ibid., p. 124. 


\section{A Taxonomy of Current Multilateral Mechanisms}

Multilateral institutions have responded to the threats posed by risky states primarily by relying on strategies which have already been developed and implemented in other contexts. The UN Secretary-General's Agenda for Peace, which focuses on security threats arising from "ethnic, religious, social, cultural or linguistic strife, advocates preventive diplomacy, peacemaking, peacekeeping, and post-conflict peace measures as the central tools available to international institutions. $^{32}$

In order to explain the current system of multilateral responses, we analyse their underlying strategic functioning. In our view, current strategies embody one or some of the following elements: rewards, promises, reconciliation, threats, or punishments. We assume that the institutions initiating a strategy can make a choice on a scale ranging from positive to negative means, with reconciliation mechanisms representing neutral treatment. These categories partly reflect Baldwin's typology of what he calls "economic statecraft". ${ }^{33}$ One of his main distinctions is between positive and negative sanctions. He also argues that a measure is deemed a reward or a punishment, threat or promise, depending on the target actor's baseline of expectations.

Most mechanisms are mixtures of these ideal types. For example, the reward to a risky state of granting admittance to a multilateral organisation may be coupled with certain penalties for noncompliance. International organisations like NATO or the European Union have implicit entry and exclusion thresholds. ${ }^{34}$ Such thresholds entail punishments and rewards; if a state complies with an organisational demand it may subsequently be granted membership into that organisation. Obversely, a state may be expelled from an organisation for overstepping the bounds set implicitly or explicitly by an organisation. The Council of Europe, for instance, has an unequivocal policy that member states respect minority rights domestically. The threat of punishment is a significant force in maintaining the institutional arrangement. A further example of the dynamic we are alluding to is the International Monetary Fund's (IMF) agreements to give loans to developing states on the condition that these states implement programmes of development supervised by the IMF.

We also distinguish short from long term mechanisms. Short term mechanisms refer to strategies to counter the use of force employed by a risky state. Long term mechanisms, by contrast, try to prevent a government with a high risk potential from resorting to the use of force. Further, promises often culminate in rewards; threats may lead to punishments if the risky state does not live up to the imposed conditions. Although the different elements of the connected strategies are often hard to disentangle, we follow Baldwin and distinguish between conditional and actual sanctions. Considerable time may pass between the issuing of a threat or promise to the actual implementation of a punishment or reward.

32. Boutros Boutros-Ghali, An Agenda for Peace: Report for the Secretary-General (New York: United Nations, 1992).

33. David A. Baldwin, Economic Statecraft (Princeton, NJ: Princeton University Press, 1985).

34. Schneider and Weitsman,"Cooperation Among Equals: A Theory of Regional Cooperation", Paper presented to the Annual Meeting of the American Political Science Association, 1994. 
Table 2. Multilateral mechanisms for eliciting co-operative behaviour from a risky state

\begin{tabular}{|c|c|c|}
\hline $\begin{array}{l}\text { Ideal type } \\
\text { mechanism }\end{array}$ & $\begin{array}{l}\text { Time } \\
\text { horizon }\end{array}$ & Operational examples \\
\hline Reward & $\begin{array}{l}\text { Short term } \\
\text { Long term }\end{array}$ & $\begin{array}{l}\text { - Lifting of threats or sanctions } \\
\text {-Ending of diplomatic quarantine } \\
\text {-Financial assistance } \\
\text {-Granting of membership to IGO }\end{array}$ \\
\hline Promise & $\begin{array}{l}\text { Short term } \\
\text { Long term }\end{array}$ & $\begin{array}{l}\text {-Partial withdrawal of multilateral force } \\
\text { - Negotiations over sanctions } \\
\text { - Negotiations over an aid package } \\
\text {-Observatory status in an IGO }\end{array}$ \\
\hline Reconciliation & $\begin{array}{l}\text { Short term } \\
\text { Long term }\end{array}$ & $\begin{array}{l}\text {-Mediation } \\
\text {-Peace keeping } \\
\text {-Preventive diplomacy } \\
\text {-Supervision of a truce }\end{array}$ \\
\hline Threat & $\begin{array}{l}\text { Short term } \\
\text { Long term }\end{array}$ & $\begin{array}{l}\text {-Immediate deterrence } \\
\text { - Suspension of IGO membership } \\
\text { - Potential deterrence } \\
\text { - Norms against risky behaviour }\end{array}$ \\
\hline Punishment & $\begin{array}{l}\text { Short term } \\
\text { Long term }\end{array}$ & $\begin{array}{l}\text {-Military intervention } \\
\text {-Economic sanctions } \\
\text {-Prosecution of leaders } \\
\text {-Exclusion from IGO }\end{array}$ \\
\hline
\end{tabular}

Table 2 summarises our categorisation of ideal type multilateral mechanisms. It also describes their time-horizon and offers some illustrative examples.

Rewards usually involve material recognition for a change in behaviour. This mechanism is structurally similar to a sidepayment to a recalcitrant legislator in a domestic setting. In an ongoing conflict, a multilateral actor may ease certain threats or punishments in recognition of moderation in the risky state's actions. The ending of a diplomatic quarantine constitutes a particularly pertinent example of a short term reward with largely symbolic value. It can take the form of an official meeting between the government leader of a risky state and some high-level functionary of the international agency.

Long term rewards range from financial assistance to the inclusion of the risky state in a major multilateral institution. When states join an organisation, their range of policy options is reduced..$^{35}$ The treatment of Germany by the US and Western Europe after the Second World War shows that such strategies may elicit the desired effects. Co-operation may be induced through learning and altering of perceptions of national interest. Interestingly, using long term strategies to elicit co-operation through offering membership in an organisation is one of the arguments used by proponents of NATO enlargement. "Expansion of

35. The repeated games by Schneider and Weitsman op. cit. shows how membership in international institutions oblige states to coordinate policies with other states. In any multilateral arrangements, there are implicit enforcement mechanism which make cooperation possible despite the wish by some constituencies to defect. 
NATO is a logical and essential consequence of the disappearance of the Iron Curtain and the need to widen European unity based on shared democratic values ... [Partnership for Peace] is an invaluable tool that encourages NATO and individual partners to work together. It helps newly democratic states restructure and establish democratic control of their military forces and learn new forms of military doctrine, environmental control, and disaster relief" ${ }^{\prime \prime}{ }^{36}$

Promises offer risky states a final reward once certain conditions are met. In an ongoing conflict, the partial withdrawal of a multilateral force and talks about lifting sanctions are promises that some reward might follow if the problem state complies with the institutional demand. The start of negotiations over an aid package or the granting of observatory status in an IGO are the functional equivalents in a more extended time frame.

With reconciliation strategies, institutions do not take sides in favour or against risky states. These kinds of strategies include active and long term measures such as preventive diplomacy and mediation, as well as the reactive strategies of peacekeeping and supervision. In addition to neutrality, a precondition of implementing these strategies is that the risky state in question accepts the efforts by the multilateral agency. As has been witnessed time and time again, however, neutrality is difficult to maintain over time.

Threats follow the same logic as promises although they are linked to negative rather than positive incentives. Deterrence involves either the threat to inflict punishment in the event of non-compliant behaviour or denying the objective to the challenging state. The distinction can be made, however, between immediate and general deterrence which both may be appropriate strategies to deal with risky states. While the former is meant as a reaction towards an actual threat, the latter mechanism is guided towards potential danger. ${ }^{37}$ Deterrence mechanisms include intimidation tactics, like the threat to expel a member state from an organisation or the creation of international norms which try to abolish the most severe violations of human rights through the prospect of punishment. The most important issue, however, for deterrent strategies to work is the extent to which the threats are credible. This would require the major powers, or enforcers of international norms, to take strong action against risky states to discourage like behaviour in the future from other risky states.

Punishment strategies may involve the use of force to induce a change in the risky states' behaviour. A classic short term example is the sanctions which are employed more frequently than multilateral military interventions. Innovative sanctioning procedures can be illustrated by the Organisation for Security and Cooperation in Europe (OSCE) n-1 decision making procedure to isolate a single member state. Long term punishments include attempts to punish a risky state through the persecution of its ruling political elite. War crime tribunals are an additional tool which may be used in this context.

36. Richard Holbrooke, "America, A European Power", Foreign Affairs, Vol. 74, No. 2 (1995).

37. According to the standard definition, "extended immediate deterrence [is] a policy in which ... a potential attacker is actively considering the use of force". On the other hand, "extended-general deterrence ... refers to political and military competition between a potential attacker and defender in which the possibility of an armed conflict over another state is present but the potential attacker is neither actively considering the use of force nor engaging in a confrontation that threatens war". See Paul Huth, Extended Deterrence and the Prevention of War (New Haven: Yale University Press, 1988), p. 16. 


\section{The Strategic Problems of Multilateralism}

Although these strategies are linked to different incentives, they can be systematically compared. Rewards and punishments-actual sanctions-fall into the same category because they pose an adverse selection problem to the international community; that is, they can lead to the problem of inadequate responses to states with a high conflict propensity. In contrast, threats and promises - conditional sanctions-are typical in situations where the multilateral agency tells the risky state that a moderation of behaviour is necessary in order to gain a reward or to avoid a punishment.

No reward or punishment can guarantee that the behaviour of a risky state will be altered permanently. This uncertainty affects primarily the multilateral agency. In the language of non-co-operative game theory, the strategic situation is one of adverse selection. According to the original model developed to illustrate the problem, a car seller has an informational advantage over a prospective client. The buyer does not know the quality of the product; a used car could easily turn out to be a lemon. The analysis shows that uncertainty of this kind may improve the efficiency of transactions: some cars never enter the market. ${ }^{38}$ According to Rasmussen, this adverse selection model formalises "Groucho Marx's wisecrack that he would refuse to join a club that would accept him as a member". ${ }^{39}$ Inefficiencies, however, might occur in international politics if multilateral agencies under-react towards states which are risky. This is additionally true since multilateral actors will prefer weak measures to strong ones.

The international community might also withhold support for a regime which is willing to alter its behaviour, or alternatively, the international agency might pay too high a price for the co-operation of a risky state. The possibility of rewarding or punishing the wrong side will hamper the activities of the multilateral agency. In other words, in these situations international governance will not be established.

Conditional sanctions, making threats or promises to a risky state, turns the game of adverse selection into a signalling game. The interaction starts with the IGO's decision to react to a risky state's behaviour. The multilateral institution will have to decide what measures it will take. If the risky state is uncertain about the credibility of the threat or promise, and does not respond, multilateral agencies will then have to decide whether or not to implement the decision. Conversely, if the risky state does modify its behaviour, the IGO will have to determine whether or not it will make good on its promise. In this game, the multilateral agency can either live up to its announcement or refrain from implementing the policy.

A risky state can counter the multilateral agency's possibility of cheating by creating uncertainty about its own type, turning the one-sided incomplete information into a two-sided incomplete information game. This constellation of double uncertainty will result in less international collaboration than anticipated by theories which focus on the dynamics of decision making internal to the institution.

38. The original argument has been made by George Akerlof. See his "Market for Lemons: Quality Uncertainty and the Market Mechanism", Quarterly Journal of Economics, Vol. 84, No. 3 (1970).

39. Eric Rasmussen, Games and Information (Oxford: Basil Blackwell, 1990), p. 184. 
Recent advances in rational deterrence theory formalise the dilemma that no mechanism is ever completely credible. They show the extent to which reputation, asymmetric information, and learning affect the likelihood of a deterrence success. ${ }^{40}$ Although a multilateral agency might be successful in using these tools, there are no easy precepts to determine a risky state's reaction.

Although reconciliation also poses problems of signalling and adverse selection, it is basically a problem of crime and punishment. While risky states might profit from the agency's lack of oversight, the international institution can create uncertainty about the frequency of its monitoring efforts. Although there is some disagreement over the role of penalties on rule violation, these games highlight the importance of monitoring. ${ }^{41}$ Counter-intuitively, monitoring decreases if the penalties are increased.

To sum up, the strategic relationship between a multilateral agency and a risky state can lead to suboptimal levels in the provision of international governance even if all collective action problems are solved. The strategic nature of taking action weakens the effectiveness of certain institutional mechanisms. In the following, we want to discuss the problems of multilateralism in security affairs more generally and assess the shortcomings of the five ideal type mechanisms. This leads us to juxtapose the benefits of unilateral as opposed to multilateral strategies.

\section{The Three Strategic Problems of Multilateralism in Security Affairs}

In synthesising the difficulties associated with multilateralism from a strategic perspective, three problems underlying the four ideal type mechanisms become immediately clear. A first difficulty is the risk of strategic exploitation: risky states can counter the moves by a multilateral agency. Second, the multilateral agency may send the wrong signal and exacerbate the problem of misperception on the side of the risky state. And third, a multilateral agency can misperceive the identity and rationality of the target. We discuss these issues below in further detail.

\section{The Risk of Strategic Exploitation}

Although a multilateral institution may signal firmness and resolve, risky states might try to exploit the willingness of the international community to address the international security problem. A typical example is that the risky state tries to challenge the conditions set forth by the multilateral agency. Even if the multilateral agency behaves strategically, the risky state always has the capacity to develop a counter-strategy. This kind of behaviour may be illustrated by North Korea's interaction with the International Atomic Energy Association (IAEA) over verification and implementation of the Nuclear Non-Proliferation

40. For a review, see R. Harrison Wagner, "Rationality and Misperception in Deterrence Theory", Journal of Theoretical Politics, Vol. 4, No. 2 (1992).

41. See the recent controversy over this issue and compare George Tsebelis, "The Abuse of Probability in Political Analysis: The Robinson Crusoe Fallacy", American Political Science Review, Vol. 83, No. 1 (1989); Jack Hirshleifer and Eric Rasmussen, "Are Equilibrium Strategies Unaffected by Incentives?", Journal of Theoretical Politics, Vol. 4 (1992); and George Tsebelis, "Penalty and Crime: Further Theoretical Considerations and Empirical Evidence", Journal of Theoretical Politics, Vol. 5 (1993). 
Treaty (NPT). Non-compliance with the terms of the NPT ultimately undermined the multilateral effort, and required unilateral enforcement of the regime by the US.

\section{Sending the Wrong Signals and Questionable Credibility}

Another inherent problem with multilateral action is that the individual states participating in such an effort send different signals to the risky state. The difficulties in achieving consensus weaken multilateral efforts. ${ }^{42}$ In addition, because it may take a significant amount of time for the member states of an institution to agree on a course of action, the lack of a quick response may signal to the risky state that no action will be taken at all. Further, if the individual states are sending different signals, the credibility of collective action may be undermined. The inability of the member states in the League of Nations to agree on what "aggression" meant undermined its credibility in deterring Mussolini from his adventures in Ethiopia.

Even if threats are credible, there might be unintended consequences. If a certain action is supposed to deter a risky state from embarking on a course of action, the state might raise the stakes and worsen the crisis. Those who contend that the League did in fact pose a credible threat argue that this "helped push Italy into the Axis alliance". ${ }^{43}$ Another problem can be that the strategic interaction between the institution and target state goes beyond one round of play. Although iteration of the interaction may help foster cooperation, it may also prolong a social dilemma. This became strikingly clear in the action and reaction between the UN peacekeeping forces and the Bosnian Serbs.

\section{Rationality and Risky States}

Current strategies used to deal with risky states assume high levels of rationality. If there are doubts about the rationality of an actor, traditional strategies involving threats, punishments, or promises are going to become questionable. ${ }^{44}$ Much of the current strategic thinking, especially rational deterrence theory, draws heavily on so-called refinements of the Nash equilibrium concept. ${ }^{45}$ These innovations usually require the assumption that actors engage in hyperrational reasoning. They not only have to figure out what is optimal, but also what possible behaviour and assumptions of the other actors might not be rational. Some of these rather esoteric refinements carry names like "universal divinity".

One of the problems with this kind of reasoning is that it requires that actors are fully rational; that is, they have to live up to the conditions of rationality set forth by non-co-operative game theory. Yet some risky states might be boundedly rational or even irrational because they choose strategies which reflect

42. For the case of the European Union, see Gerald Schneider and Claudia Seybold, "Twelve Tongues, One Voice: An Evaluation of European Political Cooperation", European Journal of Political Research (forthcoming).

43. Betts, op. cit., p. 17.

44. Christiana Bicchieri, Rationality and Coordination (New York: Cambridge University Press, 1993), Ch. 5 .

45. See e.g. Barry Nalebuff, "Rational Deterrence in an Imperfect World", World Politics, Vol. 43, No. 3 (1991). 
little concern for the positive and/or negative incentives offered by the multilateral agency. At the moment, deterrence theory does not wholly provide us with answers to the question of how a rational agency might deal with rationally irrational and irrationally irrational actors.

\section{The Problem of Oversight}

An additional problem, fundamental to strategic interaction, is the importance of information. Like any other administration, international organisations have to develop their own system of gathering information. In the domain of international security, they have to develop a system of early warning and of monitoring to detect risky states and to observe their performance once some instrumental mechanism is put into place. Although there is a renewed interest in systematic forms of information gathering in international organisations, there is also some scepticism. In the context of the UN forecasting practices, Gordenker argues that the "centralised approach to early warning adopted by the General Assembly involves a number of serious political and management difficulties". ${ }^{46}$

While our models point out the importance of limited information, there is no doubt that multilateral agencies could improve their knowledge by moving from ad hoc information and forecasting procedures to warning systems which are grounded in the theory and methodology of the social sciences. The question is whether the extant early warning and monitoring literature is helpful in this respect. Although one proponent of deductive thinking recently claimed that "reliable prediction about fundamental policy questions need not be viewed as a distant hope, but rather as a firm reality", we are just a tad more sceptical about the current state of our discipline. ${ }^{47}$

\section{Unilateral v Multilateral Action}

In delineating the inherent weaknesses in multilateral mechanisms for eliciting co-operation from risky states, the question becomes "why bother?" Is unilateral action ultimately the only means to counter effectively risky states? In the short run, the answer might be yes. Unilateral action may be more successful in generating co-operative behaviour, as witnessed in the North Korean case. The US was better able to elicit compliance than the International Atomic Energy Association; and the coalition in the Gulf War was clearly led by the US.

In our opinion, there are four primary disadvantages to multilateral as opposed to unilateral action. First, it will be easier for a risky state to frustrate multilateral action because it is easier to drive a wedge between member states

46. Leon Gordenker, "Early Warning: Conceptual and Practical Issues", in K. Rupeshinghe and M. Kuroda (eds.), Early Warning and Conflict Resolution (London: MacMillan, 1992), p. 12. Gregg A. Beyer, "Human Rights Monitoring and the Failure of Early Warning: A Practioner's View", International Journal of Refugee Law, Vol. 2, No. 1 (1990), p. 70, offers a blunt assessment of the activities of the US agencies in charge of human rights monitoring, noting that many "officers ... are often randomly selected, poorly trained ... and inadequately supported".

47. Bruce Bueno de Mesquita and Frans N. Stokman, "Models of Exchange and of Expected Utility Maximization: A Comparison of Accuracy", in B. Bueno de Mesquita and F.N. Stokman (eds.), European Community Decision Making (New Haven and London: Yale University Press, 1994), p. 228. 
in a multilateral institution than it is to drive one between domestic coalitions supporting unilateral action. Second, the likelihood that an unclear signal is sent is greater when dealing with a multilateral agency. This, again, has to do with the need to co-ordinate national policies and the incentives to follow a cavalier seul diplomacy. The efforts of the European Union to deal with Bosnia were hampered by possible unilateral actions, as witnessed by President Mitterrand's surprise trips to Sarajevo. ${ }^{48}$

Third, the problem of misperceiving the risky actor is more pronounced in a multilateral agency since states must co-ordinate their beliefs about the target of their joint action. Fourth, and finally, monitoring is more difficult if states disagree over how to monitor certain situations, or how to gather information. On the positive side, however, to ensure long run co-operation, multilateral institutions might be the preferable path to peace. They carry more legitimacy than a single state. Once in place, multilateral frameworks might evolve into "security communities" which further facilitate co-operation. ${ }^{49}$

\section{Conclusion}

In this article, we have sought to show some of the inherent limits of multilateral mechanisms in the security domain. Instead of focusing on the traditional concerns regarding short run versus long run interests of individual states which frustrate collective action, or the difficulties in coordinating state behaviour, we examine the strategic interaction between the target, risky states, and multilateral institutions. Our analysis implies that the debate about the desirability and effectiveness of collective security arrangements in the post Cold War era needs to be recast in terms of exploring whether the institutional arrangements themselves actually alter the strategic interaction between the risky state and institution. This requires further investigation into whether the problems we have identified inhere to the institutional type. Would, for example, a collective security institution be more exploitable than a more traditional alliance? One tentative conclusion we can offer is that the degree of institutionalisation of an organisation, or the extent to which the institution reflects convergence in norms, expectations, and values, will affect its credibility. This might suggest that institutions which reflect the evolution of security communities will probably be more effective in governing than will global organisations with less convergence like the UN.

By examining the interactive nature of the game, we see that if states are uncertain about the reliability or intentions of their target, they might not be willing to use the multilateral mechanisms. Or, to put it the other way around, multilateral agencies can only elicit cooperation from states with a high conflict propensity if they possess sufficient information about their clients. In addition, risky states will be less willing to challenge or attempt to divide coalitions which reflect a high degree of institutionalisation, at least on issues of core concern to the member states. We demonstrate that institutional mechanisms of multilateral

48. Schneider and Seybold, op. cit.

49. On this issue, see Adler and Barnett, op. cit., Neta C. Crawford, "A Security Regime among Democracies: Cooperation among Iroquois Nations", International Organization, Vol. 48, No. 3 (1994); and Schneider, op. cit. 
action in the security domain fall into the categories of adverse selection, signalling, or verification games. These strategic situations share the implication that collective security might be provided at socially suboptimal levels due to the collective actors' uncertainty about a risky state.

The consequences of the strategic exchange with a risky state on the provision of collective security are more pronounced for multilateral as opposed to unilateral actors. While IGOs and other institutions might experience difficulties in attaining a consensus vis a vis an outside actor, diverging state interests might also exacerbate the problems of misperception and strategic exploitation inherent in any relationship with a risky state. There are two potential solutions to these problems. One is to make the conditionality of multilateral mechanisms more explicit. A second precept is to improve the information gathering mechanisms of international institutions. In our view, there are still unexplored ways in which social scientists could influence the early warning and monitoring systems of IGOs.

While our analysis does not yet offer critical tests of our hypotheses, there are some indications that policy makers are at least partly aware of the problematic relationship with risky states. In an assessment of the new European security system, Holbrooke writes: "the decision as to who joins NATO and when will be made exclusively by the alliance. No outside nation will exercise a veto". ${ }^{50}$ Such a statement reflects an awareness of the potential for external exploitation by nonmember states. It seems time that international relations theory becomes realistic about the prospects of cooperation. This requires that attention is paid to the capacity for manipulating multilateral organisations. Reorienting our theories does not imply the need to fall into the realist trap of completely ignoring or deriding the achievements of international institutions. Nor does it mean that we should unquestioningly subscribe to liberalist arguments about how and why collective security is the answer to eliciting cooperation from risky states. On the contrary, a pragmatic approach to international governance will reveal the specific conditions under which collaboration is both possible and effective. 